\title{
Erratum to: Synthesis in Estuarine and Coastal Ecological Research: What Is It, Why Is It Important, and How Do We Teach It?
}

\author{
W. Michael Kemp • Walter R. Boynton
}

Published online: 8 March 2012

(C) Coastal and Estuarine Research Federation 2012

\section{Erratum to: Estuaries and Coasts (2012) 35:1-22 DOI 10.1007/s12237-011-9464-9}

A caveat in the concluding section of our paper states that it would be impossible to provide a comprehensive sample of synthesis case studies that reflects all the major research areas in estuarine and coastal science. In retrospect, however, we realize that the paper generally ignores two key fields of study, which are particularly active coastal research topics. Here we correct that omission by providing a few representative studies of synthesis in these two research areas: sediment biogeochemistry and seagrass ecology. Examples of synthesis research in sediment biogeochemistry include cross-system comparisons of nitrification (Henriksen and Kemp 1988) and denitrification (Pina-Ochoa and Alvarez-Cobelas 2006) in estuaries and other aquatic systems, of benthic nutrient recycling processes (Boynton and Kemp 2008), and of sediment biogeochemical processes in different coastal habitat types (Eyre and Ferguson 2002). Other synthetic studies include an integrated comparison of differences in phosphorus cycles and buffers in rivers versus estuaries worldwide (Froelich 1988) and a

The online version of the original article can be found at http://dx.doi. org/10.1007/s12237-011-9464-9.

\section{W. M. Kemp ( $\square)$}

Horn Point Laboratory, University of Maryland,

Center for Environmental Science,

P.O. Box 775, Cambridge, MD 21613, USA

e-mail: kemp@umces.edu

\section{W. R. Boynton}

Chesapeake Biological Laboratory, University of Maryland, Center for Environmental Science,

P.O. Box 38, Solomons, MD 20688, USA derivation of empirical equations that describe factors controlling key sediment diagenetic processes (e.g., Middelburg et al. 1997). In seagrass ecology comparative statistical analysis of data quantifies the minimum environmental conditions needed for plant survival in eutrophic waters (e.g., Dennison et al. 1993; Kemp et al. 2004) and describes seagrass bed feedback effects that enhance conditions for plant growth (e.g., McGlathery et al. 2007; van der Heide et al. 2011). Recent synthetic research also quantifies the global decline of seagrass beds and the associated loss of ecosystem services (Waycott et al. 2009), while other cross-system comparisons illustrate the proportional loss of total ecosystem production attributable to these seagrass declines (e.g., Borum and Sand-Jensen 1996), and time series analyses contrast diverse patterns of seagrass response to changes in nutrient loading for different regions of a large estuarine ecosystem (e.g., Orth et al. 2010). We hope that these additions adequately reflect the importance of synthesis studies in these key research areas.

\section{References}

Borum, J., and K. Sand-Jensen. 1996. Is total primary production in shallow coastal marine waters stimulated by nitrogen loading? Oikos 76: 406-419.

Boynton, W., and W.M. Kemp. 2008. Estuaries. In Nitrogen in the marine environment, 2nd ed, ed. D. Capone, D. Bronk, M. Mulholland, and E. Carpenter, 809-866. New York: Academic.

Dennison, W., R. Orth, K. Moore, J.C. Stevenson, V. Carter, S. Kollar, P. Bergstrom, and R. Batiuk. 1993. Assessing water quality with submersed aquatic vegetation. Bioscience 43: 8694. 
Eyre, B., and A. Ferguson. 2002. Comparison of carbon production and decomposition, benthic nutrient fluxes and denitrification in seagrass, phytoplankton, benthic microalgae- and macroalgaedominated warm-temperate Australian lagoons. Marine Ecology Progress Series 229: 43-59.

Froelich, P. 1988. Kinetic control of dissolved phosphate in natural rivers and estuaries: A primer on the phosphate buffer mechanism. Limnology and Oceanography 33: 649-668.

Henriksen, K., and W.M. Kemp. 1988. Nitrification in estuarine and coastal marine sediments. In Nitrogen cycling in coastal marine environments, ed. T.H. Blackburn and J. Sørensen, 207-249. New York: John Wiley.

Kemp, W.M., R. Batiuk, R. Bartleson, P. Bergstrom, V. Carter, C. Gallegos, W. Hunley, L. Karrh, E. Koch, J. Landwehr, K. Moore, L. Murray, M. Naylor, N. Rybicki, J.C. Stevenson, and D. Wilcox. 2004. Habitat requirements for submerged aquatic vegetation in Chesapeake Bay: Water quality, light regime, and physicalchemical factors. Estuaries 27: 363-377.

McGlathery, K., K. Sundback, and I. Anderson. 2007. Eutrophication in shallow coastal bays and lagoons: The role of plants in the coastal filter. Marine Ecology Progress Series 348: 1-18.
Middelburg, J.J., K. Soetaert, and P.M.J. Herman. 1997. Empirical relationships for use in global diagenetic models. Deep-Sea Research 44: 327-344.

Orth, R., M. Williams, S. Marion, D. Wilcox, T. Carruthers, K. Moore, W.M. Kemp, W. Dennison, N. Rybicki, P. Bergstrom, and R. Batiuk. 2010. Long-term trends in submersed aquatic vegetation (SAV) in Chesapeake Bay, USA, related to water quality. Estuaries and Coasts 33: 1144-1163.

Pina-Ochoa, E., and M. Alvarez-Cobelas. 2006. Denitrification in aquatic environments: A cross-system analysis. Biogeochemistry 81: 111-130.

van der Heide, T., E. van Nes, M. van Katwijk, H. Olff, and A. Smolders. 2011. Positive feedbacks in seagrass ecosystemsEvidence from large scale empirical data. PLoS One 6(1): e16504. doi:10.1371/journal.pone.0016504.

Waycott, M.C., T. Duarte, R. Carruthers, W. Orth, S. Dennison, A. Olyarnik, J. Calladine, K. Fourqurean, A.R. Heck, G. Hughes, W. J. Kendrick, F.S. Kenworthy, and S. Williams. 2009. Accelerating loss of seagrasses across the globe threatens coastal ecosystems. Proceedings of the National Academy of Sciences 106: 1237712381. 